NBER WORKING PAPER SERIES

\title{
MINIMUM WAGES AND EMPLOYMENT: \\ A CASE STUDY OF THE FAST FOOD \\ INDUSTRY IN NEW JERSEY AND \\ PENNSYLVANIA
}

David Card

Alan B. Krueger

Working Paper No. 4509

\section{NATIONAL BUREAU OF ECONOMIC RESEARCH 1050 Massachusetts Avenue \\ Cambridge, MA 02138 \\ October, 1993}

We are grateful to the Institute for Research on Poverty, University of Wisconsin, for financial support. Thanks to Orley Ashenfelter, Charles Brown, Richard Lester, Gary Solon, and seminar participants at Princeton, Michigan State, Texas A\&M, University of Michigan, University of Pennsylvania and the NBER for comments and suggestions. We also acknowledge the expert assistance of Susan Belden, Chris Burris, Katy Grady, Geraldine Harris, and Jonathan Orszag. This paper is part of NBER's program in Labor Studies. Any opinions expressed are those of the authors and not those of the National Bureau of Economic Research. 


\title{
MINIMUM WAGES AND EMPLOYMENT: \\ A CASE STUDY OF THE FAST FOOD \\ INDUSTRY IN NEW JERSEY AND \\ PENNSYLVANIA
}

\begin{abstract}
On April 1, 1992 New Jersey's minimum wage increased from $\$ 4.25$ to $\$ 5.05$ per hour. To evaluate the impact of the law we surveyed 410 fast food restaurants in New Jersey and Pennsylvania before and after the rise in the minimum. Comparisons of the changes in wages, einployment, and prices at stores in New Jersey relative to stores in Pennsylvania (where the minimum wage remained fixed at $\$ 4.25$ per hour) yield simple estimates of the effect of the higher minimum wage.

Our empirical findings challenge the prediction that a rise in the minimum reduces employment. Relative to stores in Pennsylvania, fast food restaurants in New Jersey increased employment by 13 percent. We also compare employment growth at stores in New Jersey that were initially paying high wages (and were unaffected by the new law) to employment changes at lower-wage stores. Stores that were unaffected by the minimum wage had the same employment growth as stores in Pennsylvania, while stores that had to increase their wages increased their employment.
\end{abstract}

\author{
David Card \\ Department of Economics \\ Princeton University \\ Princeton, NJ 08544 \\ and NBER
}

\author{
Alan B. Krueger \\ Woodrow Wilson School \\ Princeton University \\ Princeton, NJ 08544 \\ and NBER
}


How do employers in a low-wage labor market respond to an increase in the minimum wage? The prediction from conventional economic theory is unambiguous: a rise in the minimum wage leads profit-maximizing employers to cut employment (Stigler (1946)). Although studies in the 1970s based on aggregate teenage employment rates usually confirmed this prediction ${ }^{1}$, earlier studies based on comparisons of employment at affected and unaffected establishments often did not (e.g. Lester $(1960,1964))$. Several recent studies that rely on a similar comparative methodology have failed to detect any negative employment effects of higher minimum wages. Analyses of the 1990-91 increases in the Federal minimum wage (Katz and Krueger (1992), Card (1992a)) and of an earlier increase in the minimum wage in California (Card (1992b)) find no adverse employment impact. A study of minimum wage floors in Britain (Machin and Manning (1993)) reaches a similar conclusion.

This paper presents new evidence on the effect of minimum wages on establishment-level employment outcomes. We analyze the experiences of 410 fast food restaurants in New Jersey and Pennsylvania following the increase in New Jersey's minimum wage from $\$ 4.25$ to $\$ 5.05$ per hour. Comparisons of employment, wages, and prices at stores in New Jersey and Pennsylvania before and after the rise in the minimum offer a simple method for evaluating the effects of the minimum wage. Comparisons within New Jersey between initially high-wage stores (those paying more than the new minimum rate prior to its 
effective date) and other stores provide a further contrast for studying the impact of the new law.

In addition to the simplicity of our empirical methodology, several other features of the New Jersey experience and our data set are also significant. First, the rise in the minimum wage occurred during a recession. The increase had been legislated two years earlier when the state economy was relatively healthy and the Democratic party controlled the state legislature. By the time of the actual increase, the unemployment rate in New Jersey had risen substantially and the Republican party controlled the legislature. Last-minute political action almost succeeded in reducing the minimum wage increase. It is unlikely that the effects of the higher minimum wage were obscured by a rising economy.

Second, New Jersey is a relatively small state with an economy that is closely linked to nearby states. We believe that a control group of fast-food stores in eastern Pennsylvania forms a natural basis for comparison with the experiences of restaurants in New Jersey. Wage variation within New Jersey, however, allows us to compare the experiences of high-wage and low-wage stores in New Jersey and test the validity of the Pennsylvania control group.

Third, we successfully followed nearly 100 percent of stores from a first wave of interviews conducted before the rise 
in the minimum wage (in February and March of 1992) to a second wave conducted 7-8 months after (in November and December of 1992). We have complete information on store closings and use the employment changes at the closed stores in our analyses. We can therefore measure the overall effect of the minimum wage on average employment and not simply its effect on surviving establishments.

Our analysis of employment trends at stores that were open for business before the increase in the minimum wage says nothing about the potential effect of minimum wages on the rate of new store openings. To measure this effect we analyze interstate differences in growth rates in the numbers of McDonald's fast food outlets between 1986 and 1991. Finally, to extend our conclusions beyond the franchised fast food industry, we compare relative changes in teenage employment rates in New Jersey, New York and Pennsylvania in the year following the minimum wage increase.

\section{The New Jersey Law}

A bill signed into law in November 1989 raised the Federal minimum wage from $\$ 3.35$ per hour to $\$ 3.80$ effective April 1 1990, with a further increase to $\$ 4.25$ per hour on April 11991 . In early 1990 the New Jersey legislature went one step further, enacting parallel increases in the state minimum wage for 1990 
and 1991 and an increase to $\$ 5.05$ per hour effective April 1 , 1992. The scheduled 1992 increase gave New Jersey the highest state minimum wage rate in the country and was strongly opposed by business leaders in the state. ${ }^{2}$

In the 2 years between passage of the $\$ 5.05$ minimum wage and its effective date, New Jersey's economy fell into recession. In addition, the state legislature shifted from a Democratic majority to a Republican majority. Concerned with the possible impact of the scheduled minimum wage hike, the legislature voted in March 1992 to split the increase over two years. The vote fell just short of the margin required to over-ride a Gubernatorial veto, and the Governor allowed the $\$ 5.05$ rate to go into effect on April 1 before vetoing the two-step legislation. Faced with the prospect of having to roll back wages for minimum-wage earners, the legislature dropped the issue. Despite a strong last-minute challenge, the $\$ 5.05$ minimum rate took effect as originally planned.

\section{Sample Design and Evaluation}

Early in 1992 we decided to evaluate the impending increase in the New Jersey minimum wage by surveying fast food restaurants in New Jersey and eastern Pennsylvania. Our choice of the fast food industry was driven by several factors. First, fast food stores are a leading employer of low-wage workers: in 1989 
franchised restaurants employed 45 percent of all workers in the eating and drinking industry. ${ }^{3}$ Second, fast food restaurants comply with minimum wage regulations and would be expected to raise wages in response to a rise in the minimum wage. Third, the job requirements and products of fast food restaurants are relatively homogeneous, making it easier to obtain reliable measures of employment, wages, and product prices. The absence of tips greatly simplifies the measurement of wages in the industry. Fourth, it is relatively easy to construct a sample frame of franchised restaurants, unlike the case for many other lowwage employers. Finally, past experience (Katz and Krueger (1992)) suggested that fast food restaurants have high response rates to telephone surveys. ${ }^{4}$

Based on these considerations we constructed a sample frame of fast food restaurants in New Jersey and eastern Pennsylvania from the Burger King, KFC, Wendy's, and Roy Rogers chains. ${ }^{5}$ The first-wave of the survey was conducted by telephone in late February and early March 1992, a little over a month before the scheduled increase in New Jersey's minimum wage. The survey included questions on employment, starting wages, prices, and other store characteristics. Copies of the questionnaires used in both waves of the survey are available on request from the authors. 
Table 1 shows that 473 stores in our sample frame had working telephone numbers when we tried to reach them in February-March 1992. Restaurants were called as many as 9 times to elicit a response. We obtained completed interviews (with some item non-response) from 410 of the restaurants, for an overall response rate of 87 percent. The response rate was higher in New Jersey (91 percent) than in Pennsylvania (72.5 percent), reflecting the fact that our interviewer made fewer callbacks to non-respondents in Pennsylvania. ${ }^{6}$ In the analysis below we investigate possible biases associated with the degree of difficulty in obtaining the first wave interview.

The second wave of the survey was conducted in November and December of 1992 , about 8 months after the minimum wage increase. Only the 410 stores that responded to the first wave were contacted in the second round of interviews. We successfully interviewed 371 (90 percent) of these stores by telephone in November 1992. Because of a concern that nonresponding restaurants might have closed, we hired an interviewer to drive to each of the 39 non-respondents and determine whether the store was still open, and conduct a personal interview if possible. The interviewer discovered that 6 restaurants were permanently closed, 2 were temporarily closed (one because of a fire, one because of road construction) and 2 were under renovation. ${ }^{7}$ Of the 29 stores open for business, all but one 
granted a request for a personal interview. As a result, we have second wave interview data for 99.8 percent of the restaurants that responded in the first wave of the survey, and information on closure status for 100 percent of the sample.

Table 2 presents the mean values of several key variables in the survey, taken over the subset of non-missing responses for each variable. Employment is set to 0 for the permanently closed stores in Wave 2 but is treated as missing for the temporarily closed stores. Means are presented for the full sample and separately for stores in New Jersey and Pennsylvania. We also show the t-statistics for the null hypothesis that the means are equal in the two states.

Rows la-1e show the distribution of stores by chain and ownership status (company-owned versus franchisee-owned). Our sample contains 171 Burger King stores, 80 KFC stores, 99 Roy Rogers stores, and 60 Wendy's stores. Restaurants in the Burger King, Roy Rogers, and Wendy's chains have comparable employment levels, hours, and prices. KFC stores are smaller, are open fewer hours, and charge more for their main entree (chicken) than other chains.

In Wave 1 average employment was 23.3 full-time equivalent workers per store in Pennsylvania, compared with an average of 20.4 in New Jersey. ${ }^{8}$ Starting wages were very similar among stores in the two states, although the average price of a "full 
meal" (medium soda, small fries, and an entree) was significantly higher in New Jersey. There were no significant interstate differences in average hours of operation, the fraction of full-time workers, or the prevalence of bonus programs to recruit new workers. ${ }^{9}$

The average starting wage at fast food restaurants in New Jersey increased by 10 percent following the rise in the minimum wage. This change is illustrated in Figure 1, where we have plotted the overall distributions of starting wages in the two states from the two waves of the survey. In Wave 1 the wage distributions in New Jersey and Pennsylvania were very similar. After the increase in the minimum wage virtually all restaurants in New Jersey that had been paying below $\$ 5.05$ per hour reported a starting wage exactly equal to the new rate. On the other hand the minimum wage increase had no apparent "spillover" effect on higher-wage restaurants in the state: the mean percentage wage change for these stores was $-3.1 \%$.

Despite the increase in relative wages, full-time equivalent employment increased in New Jersey relative to Pennsylvania. Whereas New Jersey stores were initially smaller, employment gains in New Jersey coupled with losses in Pennsylvania rendered the interstate difference small and statistically insignificant in Wave 2. Only two other variables show a relative change between Waves 1 and 2: the fraction of full-time employees, and 
the price of a meal. Both variables increased in New Jersey relative to Pennsylvania.

We can assess the reliability of our survey questions by using the responses of 11 stores that were inadvertently interviewed twice in the first wave of the survey. ${ }^{10}$ Assuming that measurement errors in the two interviews are independent of each other and independent of the true variable, the correlation between responses gives an estimate of the "reliability ratio" (the ratio of the variance of the signal to the combined variance of the signal and noise). The estimated reliability ratios are fairly high - ranging from 0.70 for full-time equivalent employment to 0.98 for the price of a meal. ${ }^{11}$

We have also examined whether restaurants with missing responses for certain key variables are different from those with complete responses. To summarize, we find that stores with missing wages or prices are similar in other respects to stores with complete data. Stores that reported employment in Wave 1 but not in Wave 2 have about average employment in Wave 1 , whereas stores that reported employment in Wave 2 but not in Wave 1 are slightly larger than average in Wave 2 . There is a significant size differential associated with the likelihood of closing after Wave 1. The 6 stores that closed were smaller than other stores (with average employment of 12.4 full-time equivalents in Wave 1 versus the overall average of 21.0$).^{12}$ 


\section{Employment Effects of the Minimum Wage Increase \\ Differences-in-Differences}

Table 3 summarizes the levels and changes in average employment per store in our survey. We present data for the overall sample (column 1), by state (columns 2 and 3), and for stores in New Jersey classified by whether the starting wage in Wave 1 was exactly $\$ 4.25$ per hour (column 5), between $\$ 4.26$ and $\$ 4.99$ per hour (column 6), or $\$ 5.00$ or more per hour (column 7). We also show the differences in average employment between New Jersey and Pennsylvania stores (column 4), and between stores in the various wage ranges in New Jersey (columns 8-9).

Row 3 of the table presents the changes in average employment between Waves 1 and 2. These entries are simply the differences between the averages for the two waves (i.e., row 2 minus row 1). An alternative estimate of the change is presented in row 4 . Here we have computed the change in employment over the subset of stores with non-missing employment in both waves, which we refer to as the balanced sample of stores. Finally in row 5 we present the average change in employment among stores with non-missing employment in both waves, treating Wave 2 employment at the 4 temporarily closed stores as 0 rather than as missing. 
As noted in Table 2, New Jersey stores were initially smaller than their Pennsylvania counterparts, but grew relative to Pennsylvania stores after the rise in the minimum wage. The relative gain (the "difference in differences" of the changes in employment) is 2.76 FTE employees (or 13 percent), with a tstatistic of 2.03. Inspection of the averages in rows 4 and 5 shows that the relative change between New Jersey and Pennsylvania stores is virtually identical when the analysis is restricted to the balanced subsample, and is only slightly smaller when Wave 2 employment at the temporarily closed stores is treated as 0 .

Within New Jersey employment expanded at the low-wage stores (those paying $\$ 4.25$ per hour in Wave 1 ) and contracted at the high-wage stores (those paying $\$ 5.00$ or more per hour). Indeed, the average change in employment among the high-wage stores (-2.16 FTE employees) is very similar to the change among Pennsylvania stores (-2.28 FTE employees). Since high-wage stores in New Jersey should have been largely unaffected by the new minimum wage, this comparison provides a specification test of the validity of the Pennsylvania control group. The test is clearly passed. Regardless of whether the affected stores are compared to stores in Pennsylvania or high-wage stores in New Jersey, the estimated employment effect of the minimum wage is positive. 
The results in Table 3 suggest that employment contracted between February and November of 1992 at fast food stores that were unaffected by the rise in the minimum wage (stores in Pennsylvania and stores in New Jersey paying $\$ 5.00$ per hour or more in Wave 1). We suspect that the source of this trend was the continued worsening of the economies of the middle-Atlantic states during 1992. ${ }^{13}$ Unemployment rates in New Jersey, Pennsylvania and New York all trended upward between 1991 and 1993, with a larger increase in New Jersey than Pennsylvania during 1992 (see below). Since sales of franchised fast food restaurants are pro-cyclical, the rise in unemployment would be expected to lower fast food employment in the absence of other factors. ${ }^{14}$

\section{Regression-Adjusted Models}

The comparisons in Table 3 make no allowance for other sources of variation in employment growth, such as differences across chains. These are incorporated in the estimates in Table 4. The entries in this table are regression coefficients from models of the form:

$$
\Delta \mathrm{E}_{\mathrm{i}}=\mathrm{a}+\mathrm{b} \mathrm{X}_{\mathrm{i}}+\mathrm{c} \mathrm{NJ}_{\mathrm{i}}+\varepsilon_{\mathrm{i}}
$$

or

(1b) $\Delta \mathrm{E}_{\mathrm{i}}=\mathrm{a}^{\prime}+\mathrm{b}^{\prime} \mathrm{X}_{\mathrm{i}}+\mathrm{c}^{\prime} \mathrm{GAP}_{\mathrm{i}}+\varepsilon_{\mathrm{i}}^{\prime}$ 
where $\Delta \mathrm{E}_{\mathrm{i}}$ is the change in employment or the proportional change in employment from Wave 1 to Wave 2 at store $\mathrm{i}, \mathrm{X}_{\mathrm{i}}$ is a set of characteristics of store $i$, and $\mathrm{NJ}_{i}$ is a dummy variable for stores in New Jersey. $\mathrm{GAP}_{i}$ is an alternative measure of the impact of the minimum wage at store $i$ based on the initial wage at that store $\left(\mathrm{W}_{\mathrm{li}}\right)$ :

$$
\begin{aligned}
\operatorname{GAP}_{\mathrm{i}} & =0 \quad \text { for stores in Pennsylvania } \\
& =0 \quad \text { for stores in New Jersey with } \mathrm{W}_{1 \mathrm{i}} \geq \$ 5.05 \\
& =\left(5.05-\mathrm{W}_{1 \mathrm{i}}\right) / \mathrm{W}_{1 \mathrm{i}} \quad \text { for other stores in New Jersey. }
\end{aligned}
$$

GAP $_{i}$ is proportional increase in wages at store $\mathrm{i}$ necessary to meet the new minimum rate. Variation in $\mathrm{GAP}_{\mathrm{i}}$ reflects both the New Jersey-Pennsylvania contrast and differences within New Jersey based on reported starting wages in Wave 1 . Indeed, the value of $\mathrm{GAP}_{i}$ is a strong predictor of the actual proportional wage change between waves 1 and 2 (R-squared=0.75), and conditional on $\mathrm{GAP}_{i}$ there is no difference in wage behavior between stores in New Jersey and Pennsylvania. ${ }^{15}$

The estimate in column 1 of Table 4 is directly comparable to the simple difference-in-differences of employment changes in column 4 , row 4 of Table 3 . The discrepancy between the two estimates is due to the restricted sample in Table 4. In Table 4 and the remaining tables in this section we restrict our analysis to the set of stores with non-missing employment and wage data in 
both waves of the survey. ${ }^{16}$ This restriction results in a slightly smaller estimate of the relative increase in employment in New Jersey.

The model in column 2 introduces a set of 4 control variables: dummies for three of the chains, and another dummy for company-owned stores. As shown by the probability values in row 6 , these covariates add little to model, and have no effect on the size of the estimated NJ dummy.

The specifications in columns 3-5 use the GAP variable to measure the effect of the minimum wage. This variable gives a slightly better fit than the simple New Jersey dummy, although its implications for the New Jersey-Pennsylvania comparison are similar. The mean value of $\mathrm{GAP}_{\mathrm{i}}$ among New Jersey stores is 0.11 . Thus the estimate in column 3 implies a 1.72 increase in FTE employment in New Jersey relative to Pennsylvania.

Since GAP ${ }_{i}$ varies within New Jersey, it is possible to add both $\mathrm{GAP}_{\mathrm{i}}$ and the New Jersey dummy to the employment model. The estimated New Jersey coefficient then provides a test of the Pennsylvania control group. When we estimate these models the coefficient of the New Jersey dummy is insignificant (with t-ratios of 0.3 to 0.7 ), implying that inferences about the effect of the minimum wage are similar whether the comparison is made across states or across stores in New Jersey with higher and lower wages. 
An even stronger test is provided in column 5, where we have added dummies representing 3 regions of New Jersey (North, Central and South) and 2 regions of eastern Pennsylvania (Allentown-Easton, and the northern suburbs of Philadelphia). These dummies control for any region-specific demand shocks, and identify the effect of the minimum wage by comparing employment changes at stores in the same region of New Jersey with higher and lower starting wages in Wave 1 . The probability value in row 6 shows no evidence of regional components in employment growth. The addition of the region dummies attenuates the GAP coefficient and raises its standard error, however, making it no longer possible to reject the null hypothesis of a 0 employment effect of the minimum wage. Nevertheless, measurement error in the starting wage would be expected to lead to some attenuation of the estimated GAP coefficient when region dummies are added to the model, because some of the true variation in GAP is explained by region. Indeed, calculations based on the estimated reliability of the GAP variable (from the set of 11 double interviews) suggest that the fall in the estimated GAP coefficient from column (4) to column (5) is just equal to the expected change attributable to measurement error. ${ }^{17}$

The models in columns 6-10 repeat the previous analysis using as a dependent variable the proportional change in 
employment at each store. ${ }^{18}$ The estimated coefficients of the $\mathrm{NJ}$ dummy and the GAP variable are uniformly positive in these models but insignificantly different from 0 at conventional levels. The implied employment effects of the minimum wage are also smaller when the dependent variable is the proportional change in employment. For example, the GAP coefficient in column 3 implies that the increase in minimum wages raised employment at New Jersey stores that initially paid $\$ 4.25$ per hour by 14 percent -- about the same magnitude as the differences in Table 3. The corresponding proportional model (column 8) implies only a 7 percent effect. As we show below, the difference is attributable to heterogeneity in the effect of the minimum wage at larger and smaller stores. The proportional change in average total employment is approximately a weighted average of the proportional changes at individual stores, using as weights the initial employment shares of the stores. Weighted versions of the proportional change models give rise to larger and statistically significant coefficients.

\section{Specification Tests}

The results in Tables 3 and 4 seem to directly contradict the prediction that a rise in the minimum wage will reduce employment. Table 5 presents several alternative specifications to investigate the robustness of this conclusion. The first row of 
the table reproduces the "base specifications" from columns 2, 4, 7 and 9 of Table 5. These are models that include chain dummies and a dummy for company-owned stores. Row 2 presents alternative estimates when we set Wave 2 employment at the 4 temporarily closed stores to 0 (expanding our sample size by 4). This addition has a small attenuating effect on the coefficient of the New Jersey dummy (since all 4 stores are in New Jersey) but less effect on the GAP coefficient (since the size of GAP is uncorrelated with the probability of a temporary closure within New Jersey).

Rows 3-5 present estimation results using alternative measures of full-time equivalent employment. In row 3, employment is defined to include non-management workers only. This change has no effect relative to the base specification. In rows 4 and 5, we include managers in FTE employment but reweight part-time workers as $40 \%$ or $60 \%$ of full-time workers (instead of 50\%). ${ }^{19}$ These changes have little effect on the models for the level of employment but yield slightly smaller point estimates in the proportional employment change models.

In row 6 we present estimates obtained from a subsample that excludes 35 stores in towns along the New Jersey shore. The exclusion of these stores -- which may have a different seasonal pattern than other stores in our sample -- leads to slightly larger minimum wage effects. A similar finding emerges in row 
7 when we add a set of dummy variables for the week of the Wave 2 interview in November or December of $1992 .{ }^{20}$

As noted earlier, our interviewer made an extra effort to survey New Jersey stores in the first wave of the survey. In particular, a higher fraction of stores in New Jersey were contacted 3 or more times. To check the sensitivity of our results to this sampling feature, we re-estimated the employment models on the subset of stores that were called back at most twice. The results, in row 8 , are very similar to the base specification.

Row 9 presents estimation results for the overall sample when the proportional employment changes are weighted by the initial level of employment in each store. In principle, weighting of the proportional changes should give rise to coefficients that are more similar to the implied proportional changes from the models estimated for changes in levels. The weighted estimates are substantially larger than the unweighted estimates, and significantly different from 0 at conventional levels. The weighted estimate of the New Jersey dummy (0.13) implies a 13 percent relative increase in New Jersey employment -- exactly the same effect as the simple difference-in-differences in Table 3.

One explanation for our finding that a rise in the minimum wage has a positive employment effect is that unobserved demand shocks within New Jersey counteracted the disemployment effects of the minimum wage. To address this possibility, rows 10 and 
11 present estimation results for stores in two narrowly defined areas: towns around Newark (row 7) and towns around Camden (row 8). In each case the sample area is identified by the first 3 digits of the store's zip code. ${ }^{21}$ Within both of these local areas changes in employment are positively correlated with the increase in wages necessitated by the rise in the minimum wage, although in neither case is the effect statistically significant. To the extent that fast food product market conditions are similar within geographic areas, these results suggest that our findings are not driven by unobserved demand shocks. Our analysis of price changes (reported below) also supports this conclusion.

A final specification check is presented in row 12 of Table 5. In this row we define the GAP variable for Pennsylvania stores as the proportional increase on wages necessary to raise the wage to $\$ 5.05$ per hour. We then fit the employment models to the subset of Pennsylvania stores. In principle the size of the wage gap should have no systematic relation with employment changes for stores in Pennsylvania. In practice, this is the case. There is no indication that the wage gap is spuriously related to employment growth.

We have also investigated whether the first-differenced specification used in our employment models is appropriate. A first-differenced model implies that the level of employment in period $t$ is related to the lagged level of employment with a 
coefficient of 1. If employment fluctuations are smoothed, however, the true coefficient of lagged employment may be less than 1. Imposing the assumption of a unit coefficient may then lead to biases. To test the first-differenced specification we reestimated models for the change in employment including Wave 1 employment as an additional explanatory variable. To overcome any mechanical correlation between base period employment and the change in employment (attributable to measurement error) we instrumented Wave 1 employment with the number of cash registers in the store in Wave 1 and the number of registers in the store open at 1:00 a.m. In all of the specifications the coefficient of Wave 1 employment is close to zero. For example, in a specification including the Gap variable and ownership and chain dummies, the coefficient of Wave 1 employment is 0.04 , with a standard error of 0.24 . We conclude that the first-differenced specification is appropriate.

\section{Full-Time and Part-Time Substitution}

Our analysis so far has concentrated on full-time equivalent employment and ignored possible changes in the distribution of full- and part-time workers. An increase in the minimum wage could lead to an increase in full-time employment relative to parttime employment for at least two reasons. First, in a conventional model one would expect a minimum wage increase 
to induce employers to substitute skilled workers and capital for minimum-wage workers. Full-time workers in fast food restaurants are typically older and may well possess higher skills than part-time workers. Thus, a conventional model predicts that stores may respond to an increase in the minimum wage by increasing the proportion of full-time workers. On the other hand, $81 \%$ of restaurants paid full-time and part-time workers exactly the same starting wage in Wave 1 of our survey. ${ }^{22}$ This suggests either that full-time workers have the same skills as parttime workers, or that equity concerns lead restaurants to pay equal wages for unequally productive workers. If full-time workers are more productive (but equally paid), there may be a second reason for stores to substitute full-time workers for parttime workers; namely, a minimum wage increase enables the industry to attract more full-time workers, and stores would naturally want to hire a greater proportion of full-time workers if they are more productive.

Row 1 of Table 6 presents the mean changes in the proportion of full-time workers in New Jersey and Pennsylvania between Waves 1 and 2 of our survey, and coefficient estimates from regressions of the change in the proportion of full-time workers on the wage gap variable, chain dummies, a companyownership dummy, and region dummies (in column 6). The results are ambiguous. The fraction of full-time workers 
increased in New Jersey relative to Pennsylvania by 7.3 percent $(\mathrm{t}$-ratio $=1.84)$, but regressions on the wage gap variable do not indicate a statistically significant shift in the fraction of full-time workers within New Jersey. ${ }^{23}$

\section{Other Employment-Related Measures}

Rows 2-4 of Table 6 present results for other outcomes that we expect to be related to the level of restaurant employment. In particular, we examine whether the rise in the minimum wage is associated with a change in the number of hours restaurants are open during a weekday, the number of cash registers in the restaurant, and the number of cash restaurants typically in operation in the restaurant at 11:00 AM. Consistent with our employment results, none of these variables shows a statistically significant decline in New Jersey relative to Pennsylvania. Similarly, regressions including the gap variable provide no evidence that the minimum wage increase led to a systematic change in any of these variables (see columns 5 and 6).

\section{Nonwage Offsets}

One explanation for our finding that a rise in the minimum wage does not lower employment is that restaurants can offset the effect of the minimum wage by reducing nonwage compensation. For example, if workers value fringe benefits and wages on a 
dollar-for-dollar basis, employers can simply reduce the level of fringe benefits by the amount of the minimum wage increase, leaving their employment costs unchanged. The main fringe benefits for fast food employees are free and reduced-price meals. In Wave 1 about $19 \%$ of fast food restaurants offered workers free meals, $72 \%$ offered reduced-price meals, and $9 \%$ offered a combination of both free and reduced-price meals. Meal programs are obvious fringe benefits to cut if the minimum wage increase forces restaurants to pay higher wages.

Rows 5 and 6 of Table 6 present estimates of the effect of the minimum wage increase on the incidence of free and reducedprice meals. The proportion of restaurants offering reduced-price meals fell in both New Jersey and Pennsylvania after the minimum wage increased, with a somewhat greater decline in New Jersey. Contrary to an offset story, however, the reduction in reduced-price meal programs was accompanied by an increase in the fraction of stores offering free meals. Relative to stores in Pennsylvania, New Jersey employers actually shifted toward more generous fringes (i.e., free rather than reduced-price meals). However, the relative shift is not statistically significant.

We continue to find a statistically insignificant effect of the minimum wage increase on the likelihood of receiving free or reduced-price meals in columns 5 and 6 , where we report coefficient estimates of the GAP variable from regression models 
for the change in the incidence of these programs. The results provide no evidence that New Jersey employers offset the minimum wage increase by reducing free or reduced-price meals.

Another possibility is that employers responded to the increase in the minimum wage by reducing on-the-job training and flattening the tenure-wage profile (see Mincer and Leighton (1981)). Indeed, one manager told our interviewer in Wave 1 that her workers were foregoing ordinary scheduled raises because the minimum wage was about to rise, and this would give all her workers a raise. To determine whether this phenomenon occurred more generally, we analyzed store managers' responses to questions on the amount of time before a normal wage increase, and the usual amount of such raises. In rows 8 and 9 we report the average changes between Waves 1 and 2 for these two variables, as well as regression coefficients from models that include the wage gap variable. ${ }^{24}$ Although the average time to the first pay raise increased by 2.5 weeks in New Jersey relative to Pennsylvania, the increase is not statistically significant. Furthermore, there is only a trivial difference in the relative change in the amount of the first pay increment between New Jersey and Pennsylvania stores.

Finally, we examined a related variable: the "slope" of the wage profile, which we measure by the ratio of the typical first 
raise to the amount of time until the first raise is given. As shown in row 10 , the slope of the wage profile flattened in both New Jersey and Pennsylvania, with no significant relative difference between states. The change in the slope is also uncorrelated with the GAP variable. In summary, we can find no indication that New Jersey employers changed either their fringe benefits or their wage profiles to offset the rise in the minimum wage. $^{25}$

\section{Price Effects of the Minimum Wage Increase}

A final issue we examine is the effect of the minimum wage on the prices of meals at fast food restaurants. A competitive model of the fast food industry implies that an increase in the minimum wage will lead to an increase in product prices. If we further assume constant returns to scale in the industry, the increase in price should be proportional to the share of minimumwage labor in total factor cost. The average restaurant in New Jersey initially paid about half its workers less than the new minimum wage. If wages rose by roughly 15 percent for these workers, and if labor's share of total costs is 30 percent, we would expect prices to rise by about 2.2 percent $(=.15 \times .5 \times$ .3) due to the minimum wage rise. ${ }^{26}$

In each wave of our survey we asked managers for the prices of three standard items: a medium soda, a small order of 
french fries, and a main course. The main course was a basic hamburger at Burger King, Roy Rogers, and Wendy's restaurants, and two pieces of chicken at KFC stores. We define a "full meal" price as the after-tax price of a medium soda, a small order of french fries, and a main course.

Table 7 presents reduced form estimates of the effect of the minimum wage increase on prices. The dependent variable in these models is the change in the logarithm of the price of a full meal at each store. The key independent variable is either a dummy indicating whether the store is located in New Jersey, or the proportional wage increase required to meet the minimum wage (the GAP variable defined above).

The estimated NJ dummy in column 1 shows that after-tax meal prices rose 3.2 percent faster in New Jersey than Pennsylvania between February and November 1992. ${ }^{27}$ The effect is slightly larger controlling for chain and companyownership (see column 2). Since the New Jersey sales tax rate fell by 1 percentage point between the waves of our survey, these estimates suggest that pre-tax prices rose $4 \%$ faster as a result of the minimum wage increase in New Jersey -- slightly more than the increase needed to fully pass through the cost increase caused by the minimum wage hike.

The pattern of price changes within New Jersey is less consistent with a simple "pass through" view of minimum wage 
cost increases. In fact, meal prices rose at approximately the same rate at stores in New Jersey with differing levels of initial wages. Inspection of the estimated GAP coefficients in columns 3-5 of Table 7 confirms that these are all positive, but insignificant at conventional significance levels.

In sum, these results provide mixed evidence that higher minimum wages result in higher fast food prices. The strongest evidence emerges from a comparison of New Jersey and Pennsylvania stores. The magnitude of the price increase is consistent with predictions from a conventional model of a competitive industry. On the other hand, we find no evidence that prices rose faster among stores in New Jersey that were most affected by the rise in the minimum wage.

\section{Store Openings}

An important potential effect of higher minimum wages is to discourage the opening of new businesses. Although our sample design allows us to estimate the effect of the minimum wage on existing restaurants in New Jersey, we cannot address the effect of the higher minimum wage on potential entrants. ${ }^{28}$ To assess the likely size of such an effect, we used national restaurant directories for the McDonald's restaurant chain to compare the numbers of operating restaurants and the numbers of newly opened restaurants in different states over the 1986-91 period. Many states adopted state-specific minimum wages in the 
late 1980s. In addition, the federal minimum increased in this period. These policies create an opportunity for measuring the impact of minimum wage laws on store opening rates across states.

The results of our analysis are presented in Table 8. We regressed two measures of the growth rate in the number of stores in each state on measures of the minimum wage in the state and other control variables (population growth and the change in the state unemployment rate). The first minimum wage measure we use is the fraction of workers in the state's retail trade industry in 1986 whose wages fell between the existing Federal minimum wage in 1986 ( $\$ 3.35$ per hour) and the effective minimum wage in the state in April 1990 (the maximum of the Federal minimum wage and the state minimum wage as of April 1990). ${ }^{29}$ The second is the ratio of the state's effective minimum wage in 1990 to the average hourly wage of retail trade workers in the state in 1986. Both of these measures are designed to gauge the degree of upward wage pressure exerted by state or Federal minimum wage changes between 1986 and 1990.

The results provide no evidence that higher minimum wage rates (relative to retail trade wages in a state) exert a negative effect on either the net number of restaurants or the rate of new openings. To the contrary, all the estimates show positive effects of higher minimum wages on the number of operating or newly 
opened stores, although many of the point estimates are insignificantly different from 0 . While this evidence is limited, we conclude that the effects of minimum wages on fast food store opening rates are probably small.

VII. Broader Evidence on Employment Changes in New Jersey

Our establishment-level analysis suggests that the rise in the minimum wage in New Jersey increased employment in the fastfood industry. Is this just an anomaly associated with our particular sample, or a phenomenon unique to the fast-food industry? Data from the monthly Current Population Survey (CPS) allow us to compare state-wide employment trends in New Jersey and the surrounding states, providing a check on the interpretation of our findings. Using monthly CPS files for 1991 and 1992 we computed employment-population rates for teenagers and adults (age 25 and older) for New Jersey, Pennsylvania, New York, and the entire U.S. Since the New Jersey minimum rose on April 1 1992, we computed the employment rates for AprilDecember of both 1991 and 1992. The relative changes in employment in New Jersey and the surrounding states then give an indication of the effect of the new law.

Table 9 presents the estimated employment rates. Comparing employment changes for adult workers it is apparent that the New Jersey labor market fared slightly worse over the 1991-92 period 
than either the U.S. labor market as a whole or labor markets in Pennsylvania or New York. Among teenagers, however, the situation was reversed. In New Jersey, teenage employment fell slightly from 1991 to 1992. In New York, Pennsylvania, and in the U.S. as a whole teenage employment rates dropped faster. Relative to teenagers in Pennsylvania and New York, the teenage employment rate in New Jersey rose by about 2.0 percentage points. Consistent with our results for the fast-food industry, the relative employment of workers most heavily affected by the minimum wage rose, rather than fell, following the enactment of the new law. We believe this state-wide evidence lends further credence to our detailed findings for the fast-food industry.

\section{Interpretation}

Our empirical findings on the effects of the New Jersey minimum wage are inconsistent with the predictions of a conventional competitive model of the fast food industry. Our findings with respect to employment are consistent with several alternative models, although none of these models can also explain the apparent rise in fast food prices in New Jersey. In this section we briefly summarize the predictions of the standard model and some simple alternatives, and highlight the difficulties posed by our findings. 


\section{Standard Competitive Model}

A standard competitive model predicts that establishment-level employment will fall if the wage is exogenously raised. For an entire industry, total employment is predicted to fall and product price is predicted to rise in response to an increase in a binding minimum wage. Estimates from the time-series literature on minimum wage effects can be used to get a rough idea of the elasticity of low-wage employment to the minimum wage. The surveys by Brown, Gilroy, and Kohen $(1982,1983)$ conclude that a 10 percent increase in the coverage-adjusted minimum wage will reduce teenage employment rates by 1 to 3 percent. Since this effect is for all teenagers, and not just those employed in low-wage industries, it is surely a lower bound on the magnitude of the effect for fast food workers. The $18 \%$ increase in the New Jersey minimum wage is therefore predicted to reduce employment at fast-food stores by 0.4 to 1.0 employees per store. Our empirical results clearly reject the upper range of these estimates, although we cannot reject a small negative effect in some of our specifications.

A possible defense of the competitive model is that unobserved demand shocks affected certain stores in New Jersey: specifically, those stores that were initially paying wages less than $\$ 5.00$ per hour. However, such localized demand shocks should also affect product prices. (In fact, in a competitive model 
product demand shocks work through a rise in prices). Although lower-wage stores in New Jersey had relative employment gains, they did not have relative price increases. Furthermore, our analysis of employment changes in two major suburban areas (around Newark and Camden) reveals than even within narrowlydefined geographic areas, employment rose faster at the stores that had to increase wages the most because of the new minimum wage.

\section{Alternative Models}

An alternative to the conventional competitive model is one in which firms are price-takers in the product market but have some degree of market power in the labor market. If fast food stores face an upward-sloping labor supply schedule, a rise in the minimum wage can potentially increase employment at affected firms and in the industry as a whole. ${ }^{30}$

This same basic insight emerges from an equilibrium search model in which firms post wages and employees search among posted offers (see Mortensen (1988)). Mortensen and Burdett (1989) derive the equilibrium wage distribution for a noncooperative wage-search/wage-posting game, and show that the imposition of a binding minimum wage can increase both wages and employment relative to the initial equilibrium. Furthermore, 
their model predicts that the minimum wage will increase employment the most at firms that initially paid the lowest wages.

Although monopsonistic models provide a potential explanation for the observed employment effects of the New Jersey minimum wage, they cannot explain the observed price effects. According to these models, industry prices should have fallen in New Jersey relative to Pennsylvania, and at low-wage stores in New Jersey relative to high-wage stores in New Jersey. Neither prediction is confirmed: indeed, prices rose faster in New Jersey than Pennsylvania, although at about the same rate at highand low-wage stores in New Jersey. Another puzzle for equilibrium search models is the absence of wage increases at firms that were initially paying $\$ 5.05$ or more per hour.

The strict link between the employment and price effects of a rise in the minimum wage may be tempered if fast food stores can vary the quality of service (e.g., the length of the queue at peak hours, or the cleanliness of stores). Another possibility is that stores altered the relative prices of their various menu items. Comparisons of price changes for the three items in our survey show slight declines $(-1.5 \%)$ in the price of french fries and soda in New Jersey relative to Pennsylvania, coupled with a steep relative increase $(8 \%)$ in entree prices. These limited data suggest a possible role for relative price changes within the fast food industry following the rise in the minimum wage. 
One way to test a monopsony model is to identify stores that were initially "supply constrained" in the labor market, and test for employment gains at these stores relative to other stores. A potential indicator of market power is the use of recruitment bonuses. As we noted in Table 2 , about $25 \%$ of stores in Wave 1 were offering cash bonuses to employees who helped find a new worker. We compared employment changes at New Jersey stores that were offering recruitment bonuses is Wave 1 , and also interacted the GAP variable with a dummy for recruitment bonuses in several different employment change models. We do not find faster (or slower) employment growth at the New Jersey stores that were initially using recruitment bonuses, or any evidence that the GAP variable had a larger effect for stores that were using bonuses.

\section{Conclusions}

Contrary to the central prediction of a text book model of the minimum wage, but consistent with a growing number of studies based on cross-sectional-time series comparisons of affected and unaffected markets or employers, we find no evidence that the rise in New Jersey's minimum wage reduced employment at fastfood restaurants in the state. Regardless of whether we compare stores in New Jersey that were affected by the $\$ 5.05$ minimum to stores in eastern Pennsylvania (where the minimum wage was 
constant at $\$ 4.25$ per hour) or to stores in New Jersey that were initially paying $\$ 5.00$ per hour or more (and were essentially unaffected by the new law), we find that the increase in the minimum wage slightly increased employment. We present a wide variety of alternative specifications to probe the robustness of this conclusion. None of the alternatives shows a negative employment effect. In addition, we find no evidence that minimum wage increases reduce the number of McDonald's outlets opened in a state. We check our findings for the fast food industry by comparing changes in teenage employment rates in New Jersey, Pennsylvania, and New York in the year following the increase in the minimum wage. Again, these results point toward a relative increase in employment of low-wage workers in New Jersey.

Finally, we find that prices of fast food meals increased in New Jersey relative to Pennsylvania, suggesting that much of the burden of the minimum wage rise was passed on to consumers. But within New Jersey we find no evidence that prices increased more at stores that were most affected by the minimum wage. Taken as a whole, these findings are difficult to explain with the standard competitive model or with models in which employers face supply constraints (e.g., monopsony or equilibrium search models). 


\section{References}

Brown, Charles, Curtis Gilroy and Andrew Kohen. 1982. "The Effect of the Minimum Wage on Employment and Unemployment." Journal of Economic Literature, Vol. 20, No. 2 (June), pp. 487-528.

Brown, Charles, Curtis Gilroy, and Andrew Kohen. 1983. "Time Series Evidence on the Effect of the Minimum Wage on Youth Employment and Unemployment." Journal of Human Resources. Vol. 18, Winter, pp. 3-31.

Burdett, Kenneth, and Dale T. Mortensen. 1989. "Equilibrium Wage Differentials and Employer Size." Center for Mathematical Studies in Economics and Management Science, Northwestern University, Discussion Paper No. 860, October.

Bureau of National Affairs. 1990. Daily Labor Report, No. 62, March 30.

Bureau of National Affairs. Undated. Labor Relations Reporter Wages and Hours Manual. Washington, DC.

Card, David. 1992a. "Using Regional Variation in Wages to Measure the Effects of the Federal Minimum Wage." Industrial and Labor Relations Review, 46, No. 1, October, pp. 22-37.

Card, David. 1992b. "Do Minimum Wages Reduce Employment? A Case Study of California, 1987-89." Industrial and Labor Relations Review, 46, No. 1, October, pp. 38-54.

International Franchising Association, 1991. Franchising in the Economy. Washington D.C. 
Katz, Lawrence, and Alan Krueger. 1992. "The Effect of the Minimum Wage on the Fast Food Industry." Industrial and Labor Relations Review, 46, No. 1, October, pp. 6-21.

Lester, Richard A. 1960. "Employment Effects of Minimum Wages." Industrial and Labor Relations Review, Vol. 13, No. 2 (January), pp. 254-64.

Lester, Richard A. 1964. The Economics of Labor. 2nd Edition. New York: Macmillan.

Machin, S. and Alan Manning. 1992. "Minimum Wages, Wage Dispersion, and Employment: Evidence from the U.K. Wages Councils." London School of Economics Unpublished Working Paper.

Mincer, Jacob and Linda Leighton. 1981. "The Effects of Minimum Wages on Human Capital Formation". In Simon Rottenberg, editor. The Economics of Legal Minimum Wages. Washington DC: The American Enterprise Institute.

Mortensen, Dale T. 1988. "Equilibrium Wage Distributions: A Synthesis." Center for Mathematical Studies in Economics and Management Science, Northwestern University, Discussion Paper No. 811.

Ransom, Michael. 1993. "Seniority and Monopsony in the Academic Labor Market." American Economic Review, Vol. 83, No. 1, pp. 221-233.

Stigler, George J. 1946. "The Economics of Minimum Wage Legislation." American Economic Review. Vol. 36, June, pp. 358-365. 
Sullivan, Daniel. 1989. "Monopsony Power in the Market for Nurses." Journal of Law and Economics, Vol. 32, No. 2 (October, part 2), pp. S135-S178.

Wellington, Alison J. 1991. "Effects of the Minimum Wage on the Employment Status of Youths: An Update." Journal of Human Resources, Vol. 26, No. 1 (Winter), pp. 27-46. 
1.See Brown, Cohen, and Gilroy $(1982,1983)$ for surveys of this literature. A recent update (Wellington (1991)) concludes that the employment effects of the minimum wage are negative but small: a 10 percent increase in the minimum is estimated to lower teenage employment rates by 0.06 percentage points.

2.See Bureau of National Affairs Daily Labor Report (May 5, 1990).

3. Total employment in franchised restaurants is reported in International Franchising Association (1991). Total employment in the fast food industry is reported in U.S. Department of Labor Employment and Earnings (1990).

4.In a pilot survey Katz and Krueger (1992) obtained very low response rates from McDonald's restaurants. For this reason, McDonald's restaurants were excluded from Katz and Krueger's and our sample frames.

5.The sample was derived from white pages telephone book listings for New Jersey and Pennsylvania as of February 1992.

6. Response rates per call-back were almost identical in the two states. Among New Jersey stores, 44.5 percent responded on the first call and 72.0 percent responded after at most 2 callbacks. Among Pennsylvania stores 42.2 percent responded on the first call and 71.6 percent responded after at most 2 callbacks.

7.By April 1993 the store closed because of road construction and one of the stores closed for renovation had re-opened. The store closed by fire was open when our telephone interviewer called in November 1992 but refused the interview. By the time of the follow-up personal interview a mall fire had closed the store. 
8. Full-time equivalent employment is defined as the number of full-time workers (including managers) plus 0.5 times the number of part-time workers. We discuss the sensitivity of our results to alternative assumptions on the measurement of employment below.

9.These programs reward current employees with a cash "bounty" for any new employee who they recruit and who stays on the job for a minimum period of time. Typical bonuses are \$50-75. We exclude programs that award an "employee of the month" designation or other non-cash bonus from our tabulation.

10.These restaurants were interviewed twice because their phone number appeared in more than one phone book, and neither the interviewer nor the respondent noticed that the store had been previously interviewed.

11. The standard errors of these ratios are 0.19 and 0.02 , respectively. Similar reliability ratios for very similar questions are reported by Katz and Krueger (1992).

12.A probit analysis of the probability of closure shows that the initial size of the store is a significant predictor of closure. The level of starting wages has a numerically small and statistically insignificant coefficient in the probit model.

13. An alternative possibility is that seasonal factors produce higher employment at fast food restaurants in February and March than in November and December. An analysis of national employment data for food preparation and service workers, however, shows higher average employment in the fourth quarter than the second quarter.

14. To investigate the cyclicality of fast food restaurant sales we regressed the year-to-year change in U.S. sales of the McDonald's restaurant chain from 1976-91 on the 
corresponding change in the average unemployment rate. The regression results show that a one percentage point increase in the unemployment rate reduces sales by $\$ 257$ million, with a $t-$ statistic of 3.0 .

15.A regression of the proportional wage change between waves 1 and 2 on $\mathrm{GAP}_{\mathrm{i}}$ has a coefficient of 1.03 .

16. Stores that closed are assigned a wage rate in Wave 2 equal to the average for their state.

17.In a regression model without other controls the expected attenuation of the GAP coefficient due to measurement error is the reliability ratio of GAP $\left(\gamma_{0}\right)$, which we estimate at 0.70 . The expected attenuation factor when region dummies are added to the model is $\gamma_{1}=\left(\gamma_{0}-R^{2}\right) /\left(1-R^{2}\right)$, where $R^{2}$ is the Rsquared of a regression of GAP on region effects (equal to 0.30). Thus, we expect the estimated GAP coefficient to fall by a factor of $\gamma_{1} / \gamma_{0}=0.8$ when region dummies are added to a regression model.

18. We have divided the change in employment by average employment in Waves 1 and 2. This results in very similar coefficients but smaller standard errors than the alternative of dividing by Wave 1 employment. For closed stores the proportional change in employment is set to -1 .

19. Analysis of the 1991 Current Population Survey reveals that part-time workers in the restaurant industry work about $46 \%$ as many hours as full-time workers. Katz and Krueger (1992) report that the ratio of part-time workers' hours to full-time workers' hours in the fast food industry is 0.57 .

20. We also added dummies for the interview dates for the Wave 1 survey, but these were insignificant and did not change the estimated minimum wage effects. 
21. The '070' 3-digit zip code area (around Newark) and the '080' 3-digit zip code area (around Camden) have by far the largest numbers of stores among 3-digit zip code areas in New Jersey, and together account for 36 percent of New Jersey stores in our sample.

22.In the other $19 \%$ of stores full-time workers are paid more, typically 10 percent more.

23. Within New Jersey, the fraction of full-time employees increased about as quickly at stores with higher and lower wages in Wave 1.

24.In Wave 1 , the average time to a first wage increase was 18.9 weeks, and the average amount of the first increase was $\$ 0.21$ per hour.

25. Katz and Krueger (1992) report that a significant fraction of fast food stores in Texas responded to an increase in the minimum wage by raising wages for workers who were initially earning more than the new minimum rate. Our results on the slope of the tenure profile are consistent with their findings.

26. According to the McDonald's 1991 Annual Report, payroll and benefits are 31.3 percent of operating costs at companyowned stores.

27. The effect is attributable to a 2.0 percent increase in prices in New Jersey and a -1.0 percent decrease in prices in Pennsylvania.

28. Direct inquiries to the chains in our sample revealed that Wendy's opened 2 stores in New Jersey in 1992 and 1 store in Pennsylvania. The other chains were unwilling to provide information on new openings. 
29. We used the 1986 Current Population Survey merged monthly file to construct the minimum wage variables. State minimum wage rates in 1990 were obtained from Bureau of National Affairs (1990).

30.Sullivan (1989) and Ransom (1993) present empirical results for nurses and university teachers that suggest monopsony-like behavior of employers. 
Figure 1

Distribution of Starting Wage Rates

February 1992

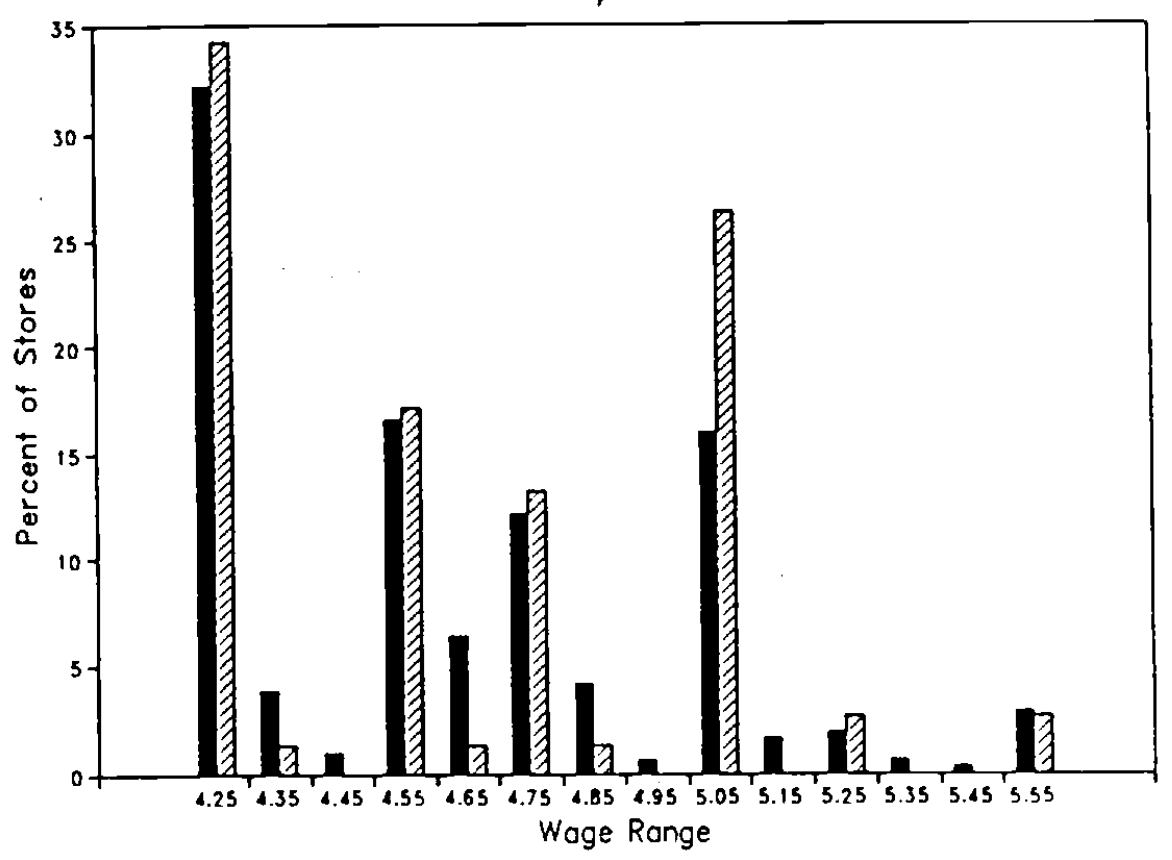

November 1992

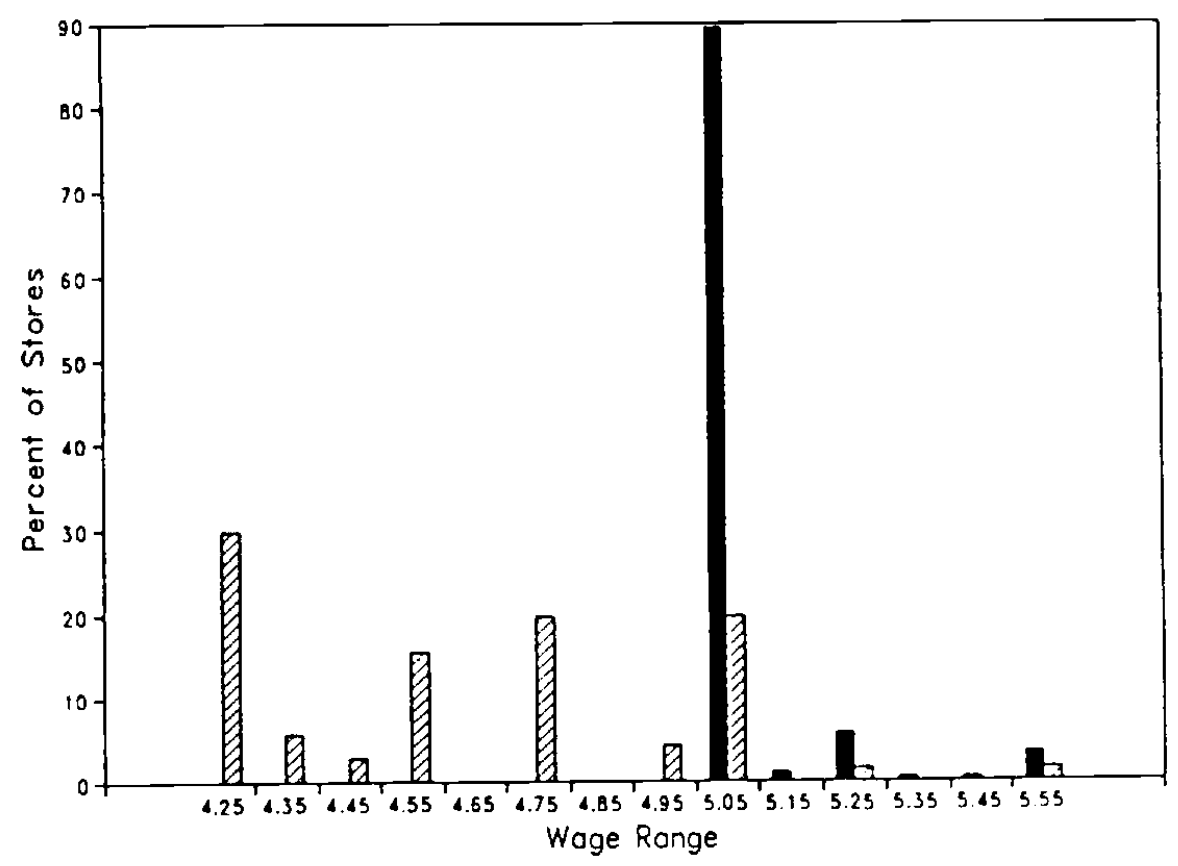

New Jersey 


S Stores in:

Wave 1: February 15-March 41992

$\begin{array}{lccc}\text { 1. Number of stores in somple frome } & 109 \\ \text { 2. Number of Refusals } & 473 & 364 & 30 \\ \text { 3. Number Interviewed } & 63 & 33 & 79 \\ \text { 4. Response Rate }(x) & 86.7 & 90.9 & 72.5\end{array}$

Wove 2: November 5-December 311992

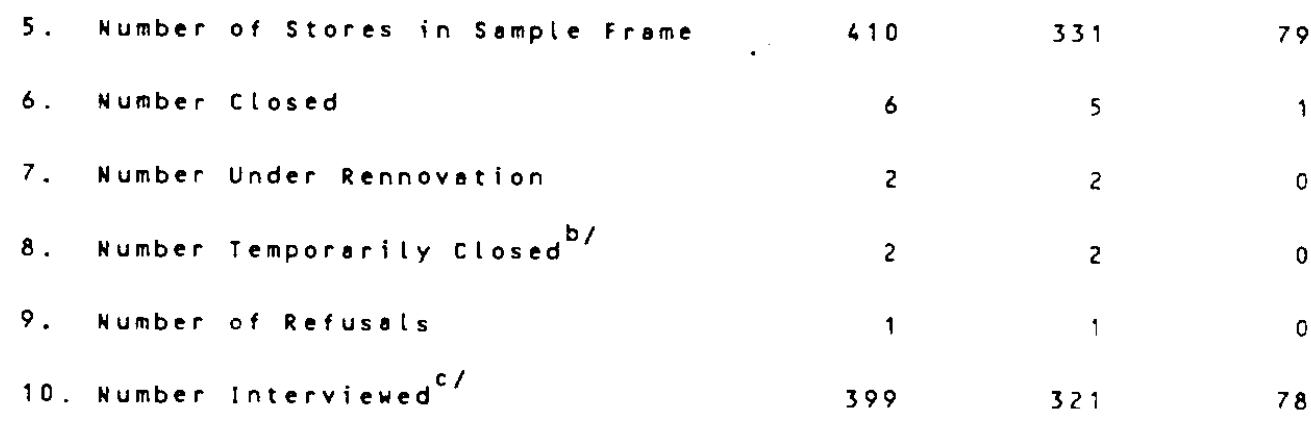

\footnotetext{
Notes: a/ stores with working phone numbers only. 29 stores in original sample frame had disconnected phone numbers.

b/

Includes one store closed because of highway construction and one store closed because of a fire.

c/

Includes 371 phone interviews and 28 personal interviews of stores that refused on initial request for a phone interview.
} 


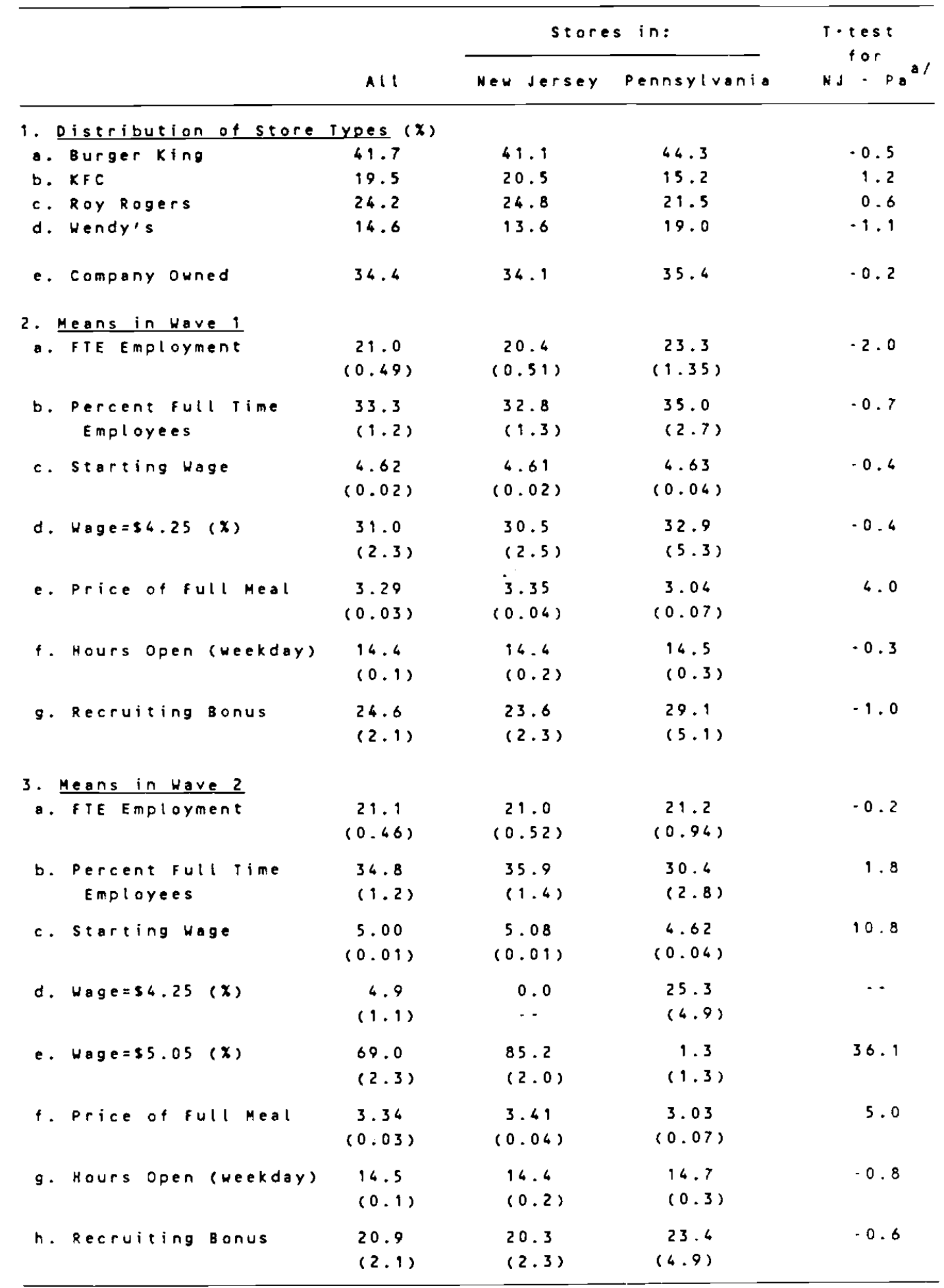

Notes: See text for definitions. Standard errors in parentheses. a/ -statistic for test of equality of means in $N J$ and $p a$. 


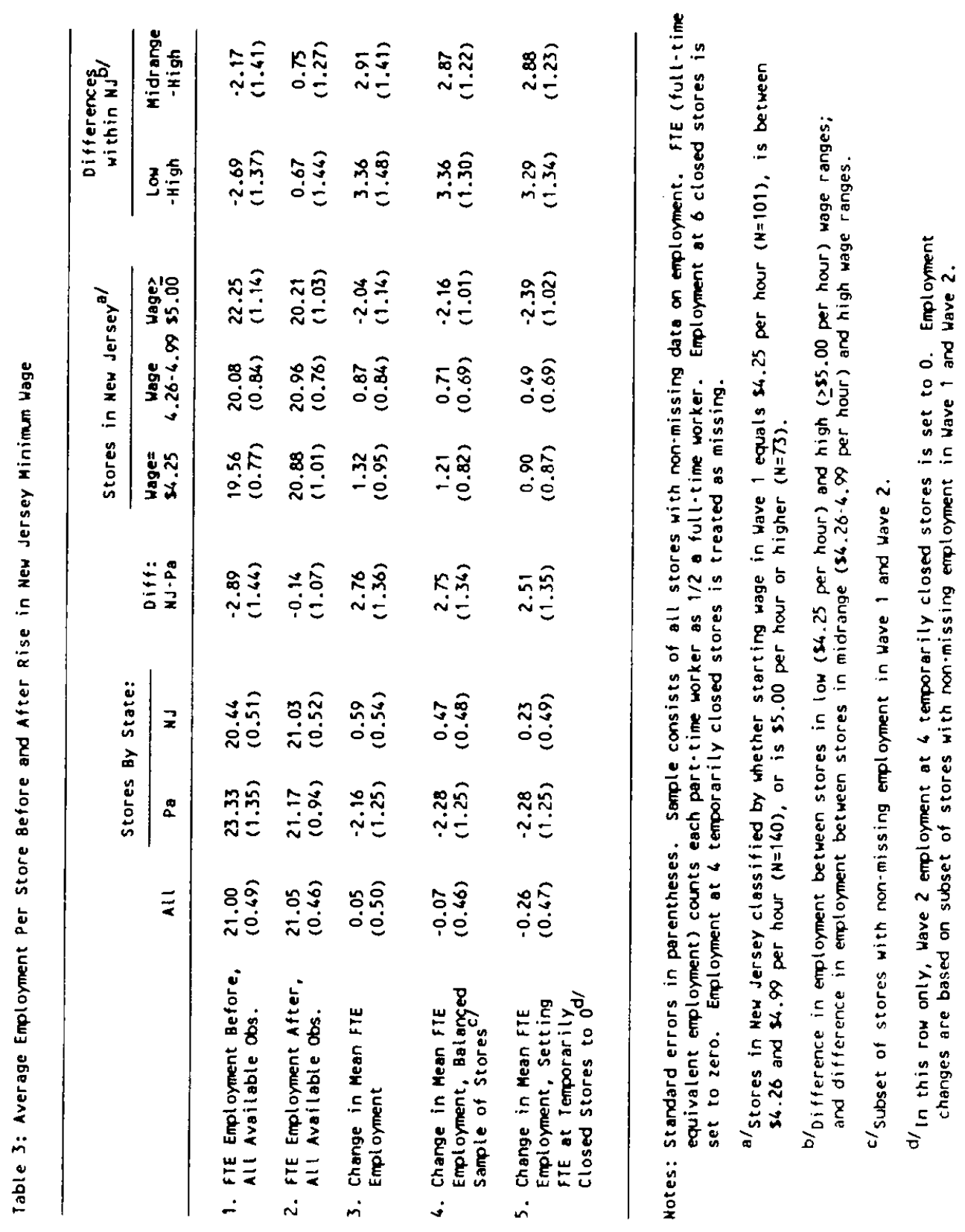




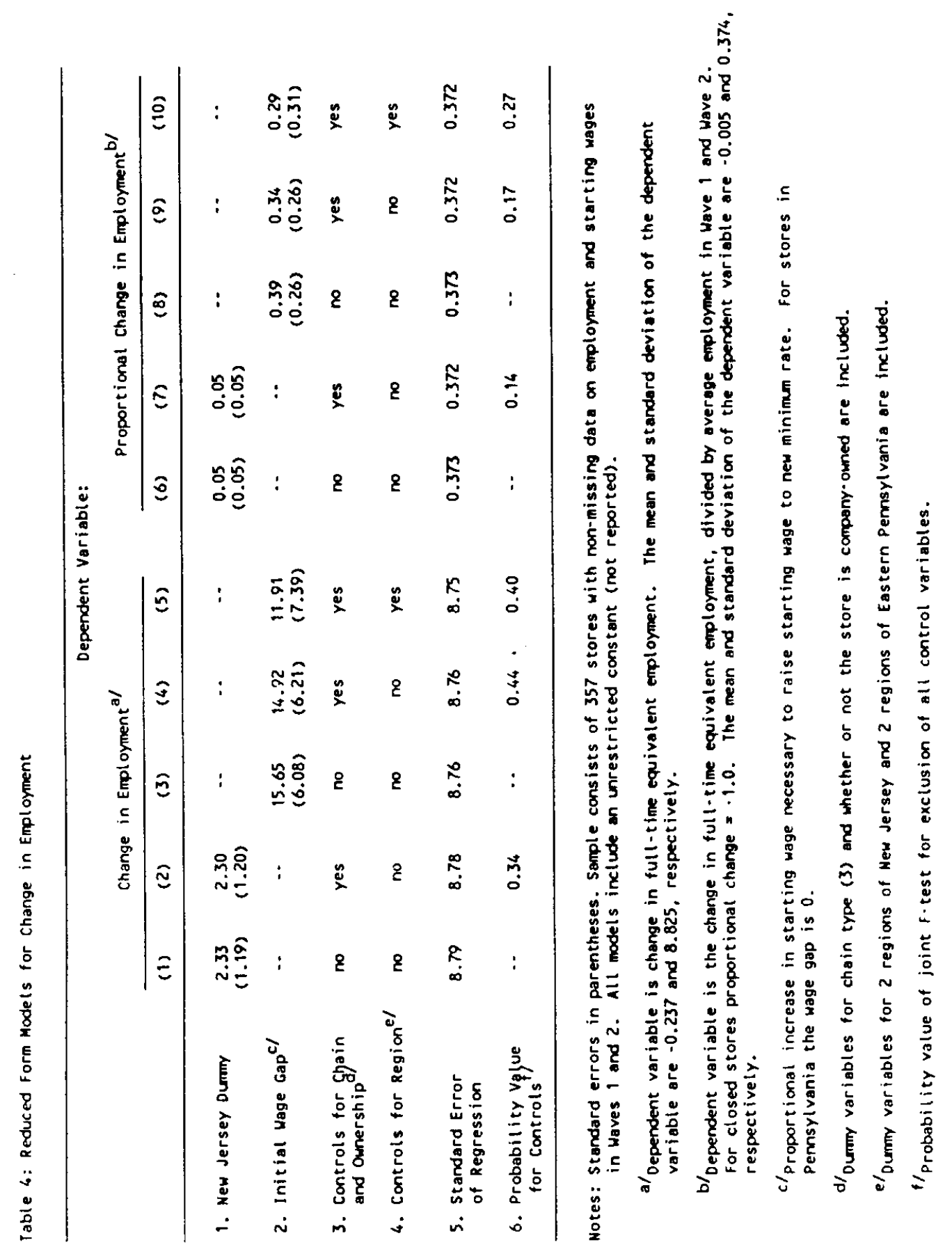


Table 5: Specification tests of Reduced form Employment Models

\begin{tabular}{|c|c|c|c|c|c|c|}
\hline & & \multicolumn{3}{|c|}{$\begin{array}{l}\text { Change in } \\
\text { Employment }\end{array}$} & \multicolumn{2}{|c|}{$\begin{array}{c}\text { Proportional Change i } \\
\text { Employment }\end{array}$} \\
\hline & & NS & $\begin{array}{l}\text { Dummy } \\
\text { (1) }\end{array}$ & $\begin{array}{l}\text { Gap Measure } \\
\text { (2) }\end{array}$ & $\begin{array}{c}\text { No Dumy } \\
\text { (3) }\end{array}$ & $\begin{array}{l}\text { Gap Measure } \\
\text { (4) }\end{array}$ \\
\hline 1. & Base Specification & & $\begin{array}{l}2.30 \\
(1.19)\end{array}$ & $\begin{array}{l}14.92 \\
(6.21)\end{array}$ & $\begin{array}{l}0.05 \\
(0.05)\end{array}$ & $\begin{array}{l}0.34 \\
(0.26)\end{array}$ \\
\hline 2. & $\begin{array}{l}\text { Treat } 4 \text { Temporarily } \\
\text { closed stores as } \\
\text { Permanently closed }\end{array}$ & & $\begin{array}{l}2.20 \\
(1.21)\end{array}$ & $\begin{array}{l}14.42 \\
(6.31)\end{array}$ & $\begin{array}{l}0.04 \\
(0.05)\end{array}$ & $\begin{array}{c}0.34 \\
(0.27)\end{array}$ \\
\hline 3. & $\begin{array}{l}\text { Exclude Managers in } \\
\text { Employment count }\end{array}$ & & $\begin{array}{l}2.34 \\
(1.17)\end{array}$ & $\begin{array}{l}14.69 \\
(6.05)\end{array}$ & $\begin{array}{l}0.05 \\
(0.07)\end{array}$ & $\begin{array}{l}0.28 \\
(0.34)\end{array}$ \\
\hline 4. & $\begin{array}{l}\text { Weight part-time } \\
\text { as } 0.4 \text { Full-time }\end{array}$ & & $\begin{array}{l}2.34 \\
(1.20)\end{array}$ & $\begin{array}{l}15.23 \\
(6.23)\end{array}$ & $\begin{array}{l}0.06 \\
(0.06)\end{array}$ & $\begin{array}{l}0.30 \\
(0.33)\end{array}$ \\
\hline 5. & $\begin{array}{l}\text { Weight Part-time d/ } \\
\text { as } 0.6 \text { full-time }\end{array}$ & & $\begin{array}{l}2.27 \\
(1.21)\end{array}$ & $\begin{array}{l}14.60 \\
(6.26)\end{array}$ & $\begin{array}{l}0.04 \\
(0.06)\end{array}$ & $\begin{array}{c}0.17 \\
(0.29)\end{array}$ \\
\hline 6. & $\begin{array}{l}\text { Exclude stores, in } \\
\text { Ns Shore Area }\end{array}$ & & $\begin{array}{l}2.58 \\
(1.19)\end{array}$ & $\begin{array}{l}16.8 B \\
(6.36)\end{array}$ & $\begin{array}{l}0.06 \\
(0.05)\end{array}$ & $\begin{array}{l}0.42 \\
(0.27)\end{array}$ \\
\hline 7. & $\begin{array}{l}\text { Add Controls for } \\
\text { Wave } 2 \text { Interview } \\
\text { Date }\end{array}$ & & $\begin{array}{l}2.27 \\
(1.20)\end{array}$ & $\begin{array}{l}15.79 \\
(6.24)\end{array}$ & $\begin{array}{l}0.05 \\
(0.05)\end{array}$ & $\begin{array}{l}0.40 \\
(0.26)\end{array}$ \\
\hline 8. & $\begin{array}{l}\text { Exclude stores } \\
\text { called More than } \\
\text { Twice in wave, }\end{array}$ & & $\begin{array}{l}2.41 \\
(1.28)\end{array}$ & $\begin{array}{l}14.08 \\
(7.11)\end{array}$ & $\begin{array}{l}0.05 \\
(0.05)\end{array}$ & $\begin{array}{c}0.31 \\
(0.29)\end{array}$ \\
\hline 9. & $\begin{array}{l}\text { Weight by thitiol } \\
\text { Employment }\end{array}$ & & $\cdots$ & $-\cdot$ & $\begin{array}{l}0.13 \\
(0.05)\end{array}$ & $\begin{array}{l}0.81 \\
(0.26)\end{array}$ \\
\hline 10. & $\begin{array}{l}\text { stores in Towns } \\
\text { around Newark }\end{array}$ & & $\cdots$ & $\begin{array}{l}33.75 \\
(16.75)\end{array}$ & $\cdots$ & $\begin{array}{c}0.90 \\
(0.74)\end{array}$ \\
\hline 11. & $\begin{array}{l}\text { Stores in Towns, } \\
\text { around cambden }\end{array}$ & & $\cdots$ & $\begin{array}{l}10.91 \\
(14.09)\end{array}$ & $\cdots$ & $\begin{array}{l}0.21 \\
(0.70)\end{array}$ \\
\hline 12. & $\begin{array}{l}\text { Pennsylvania stores } \\
\text { only }\end{array}$ & & $\cdots$ & $\begin{array}{c}.0 .30 \\
(22.00)\end{array}$ & $\cdots$ & $\begin{array}{l}-0.33 \\
(0.74)\end{array}$ \\
\hline
\end{tabular}

Notes: Standarderrors in parentheses. Entries represent estimated coefficient of New sersey dummy (columns 1 and 3 ) or initial wage gap (columns 2 and 4 ) in regresion models for the change in employment or the percentage change in employment. All models a lso include chain dummies and an indicator for company-owned stores. 


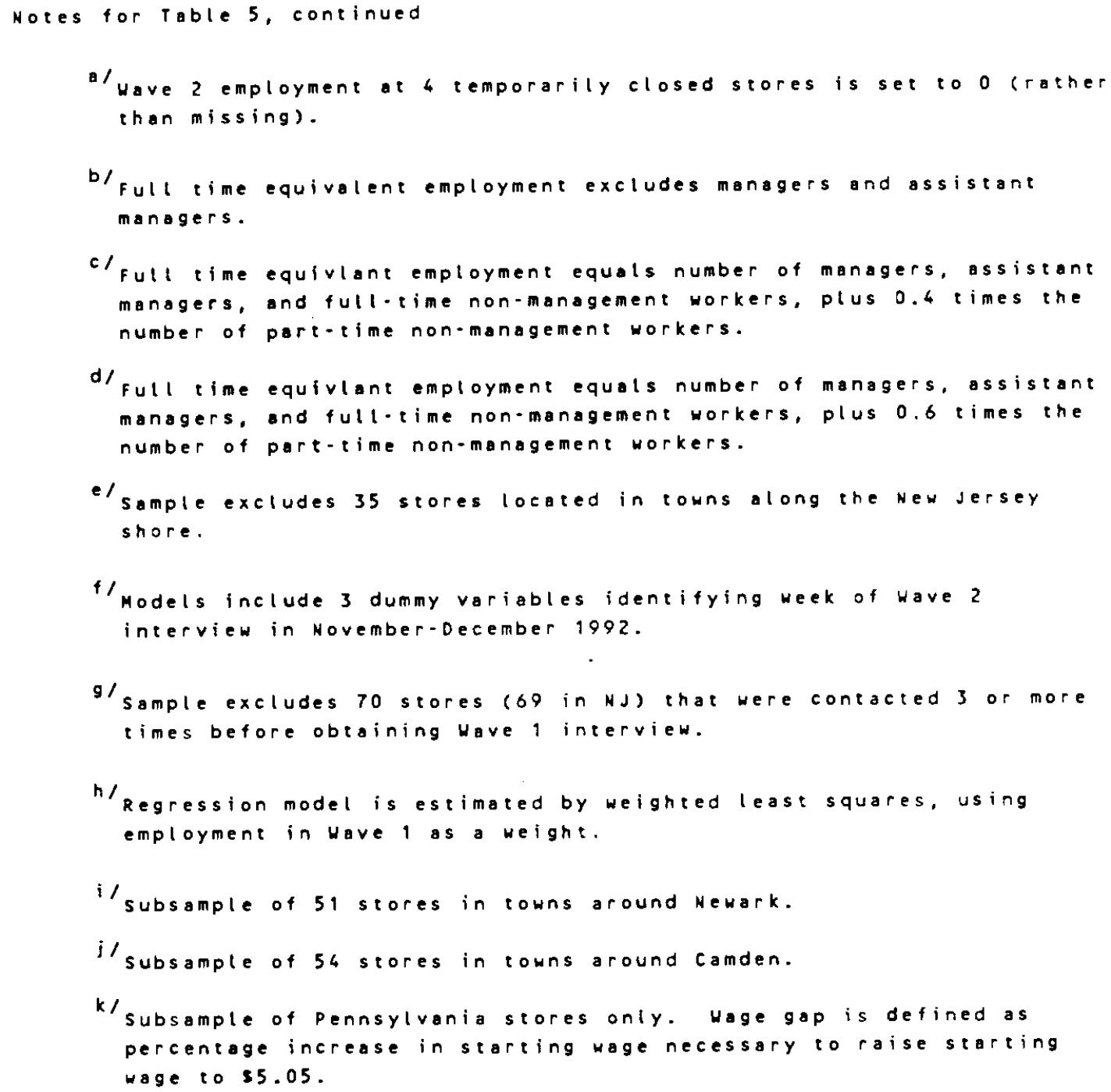


Table 6: Effects of minimum wage Increose on other outcomes

Mean
Chonge in outcome:

OUTCOME MEASURE:

store characteristics

1. Fraction Full.time horkers $(x)$

$(1.71)$

$-4.65$

7.20

7.30

33.66

20.28

2. Number of Hours

open per weekday

$\begin{array}{rrr}-0.00 & 0.11 & -0.11\end{array}$

$(0.06)$

(0.08)

$(0.10)$

(3.96)

(20.95)

$(26.36)$

3. Number of Cash

Registers

.0 .04

$0.13 \quad-0.17$

$-0.1 i$

.0 .26

0.06

-0.04
$(0.04)$

(0.10)

(0.11)

$(0.12)$

$(0.65)$

(0.76)

4. Number of Cosh

Registers open

$-0.18$

- 0.31

0.28

$(0.10)$

$(0.53)$

$(0.62)$

at 11:00 om

Employee Meol progroms

5. Low.price Meol

Program ( $x$ )

6. Free Meal

program (x)

7. Combination of low Price and free

Meals ( $x$ ) $\begin{array}{lll}-0.03 & 0.20 & 0.17\end{array}$

$(0.05)$

(0.08)

$(0.10)$

$-4.67$

$(2.65)$

$-1.28$

(3.86)

.3 .39

(4.68)

8.41

(2.17)

0.47

2.00

.4 .04

(1.98)

$(3.33)$

(3.97)

$-5.13$

(3.11)

1.09

$(3.69)$

0.17

(0.12)

0.15

$(0.62)$

$-0.67$

$(0.76)$

.2 .01

.30 .31

(5.03)

(20.80)

33.15

0.40

20.80

(4.50)

(23.75)

1. 20

.11 .87

(4.32)

$(22.87)$

$-10.12$

(20. $8:$ :

Wage profile

8. Time to first Raise (weeks)

(0.89)

1.26

2. 51

(1.97)

(2.16)

9. Usual Amount of First Raise (cents)

$-0.09$

$-0.02$

0.01

$(0.01)$

$(0.02)$

$(0.02)$

10. Slope of Wage

Profile ( $x$ per week)

$-0.10 \quad-0.11$

0.01

$(0.06)$

(0.09)

(0.10)

2.21

(2.03)

4.02

$(: 0.81)$

$5 .: \mathrm{C}$

(12.76)

$(0.02)$

0.03

(0.11)

ใ. 33

10.: :

0.01

(0.10)

$-0.07$

(0.53)

- 0.0 .8

(o.si) 


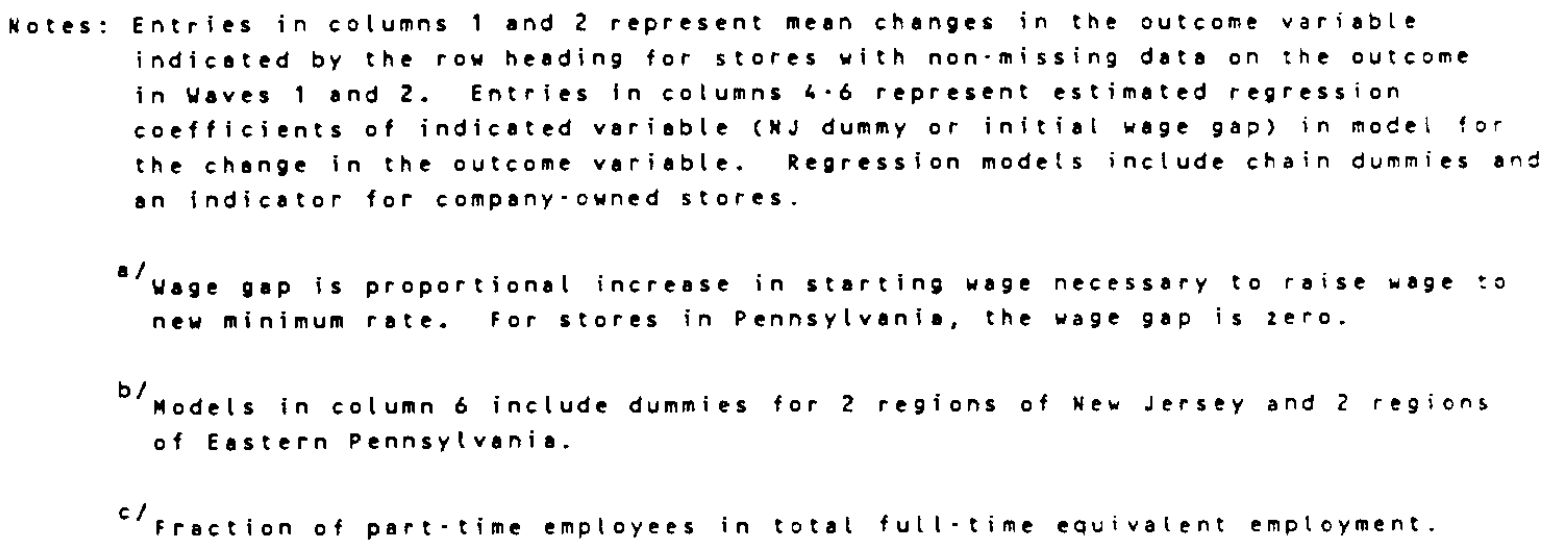

claraction of part-time employees in total full-time equivalent employment. 
Table 7: Reduced Form Models for change in the Price of full Meal

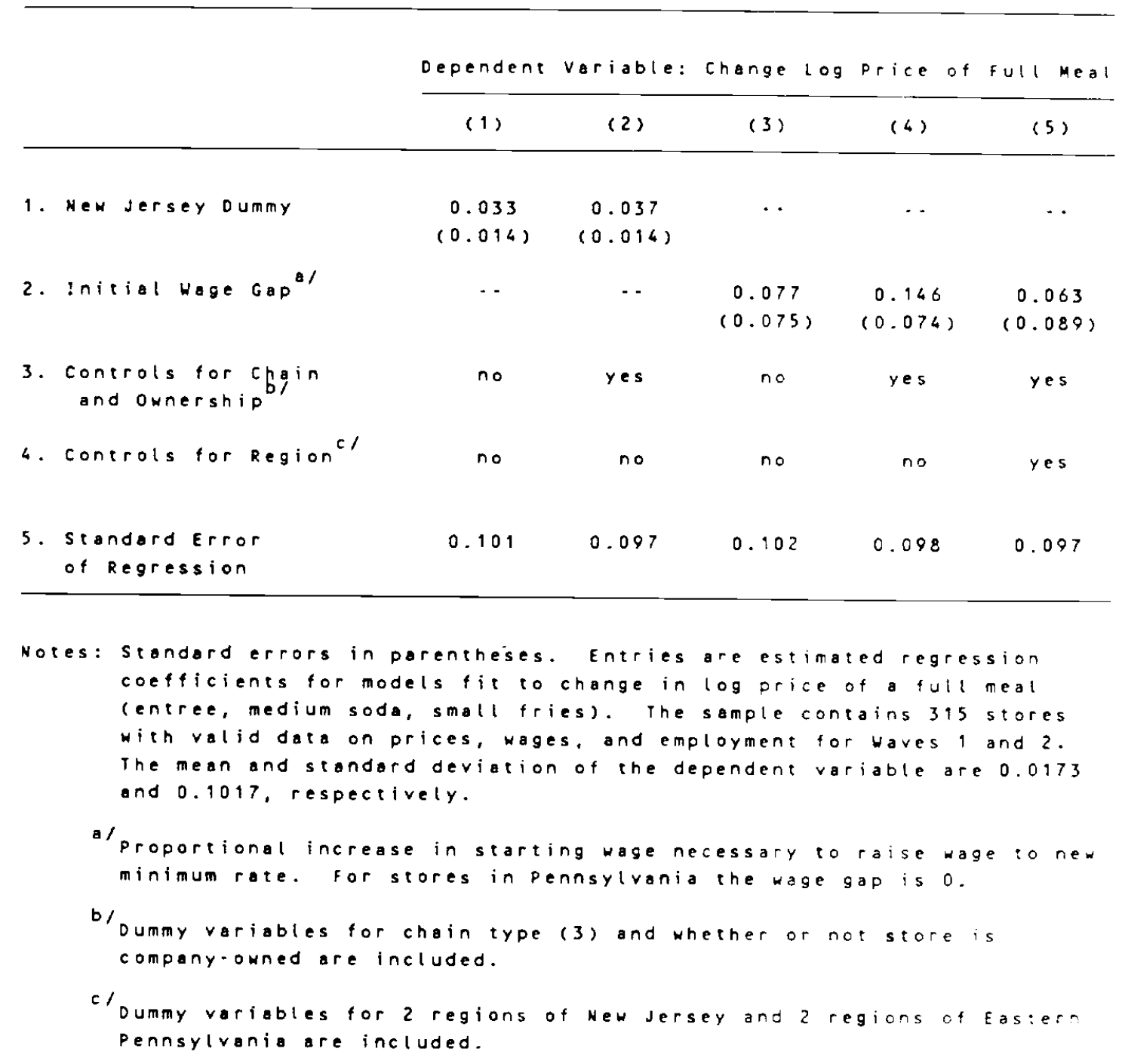




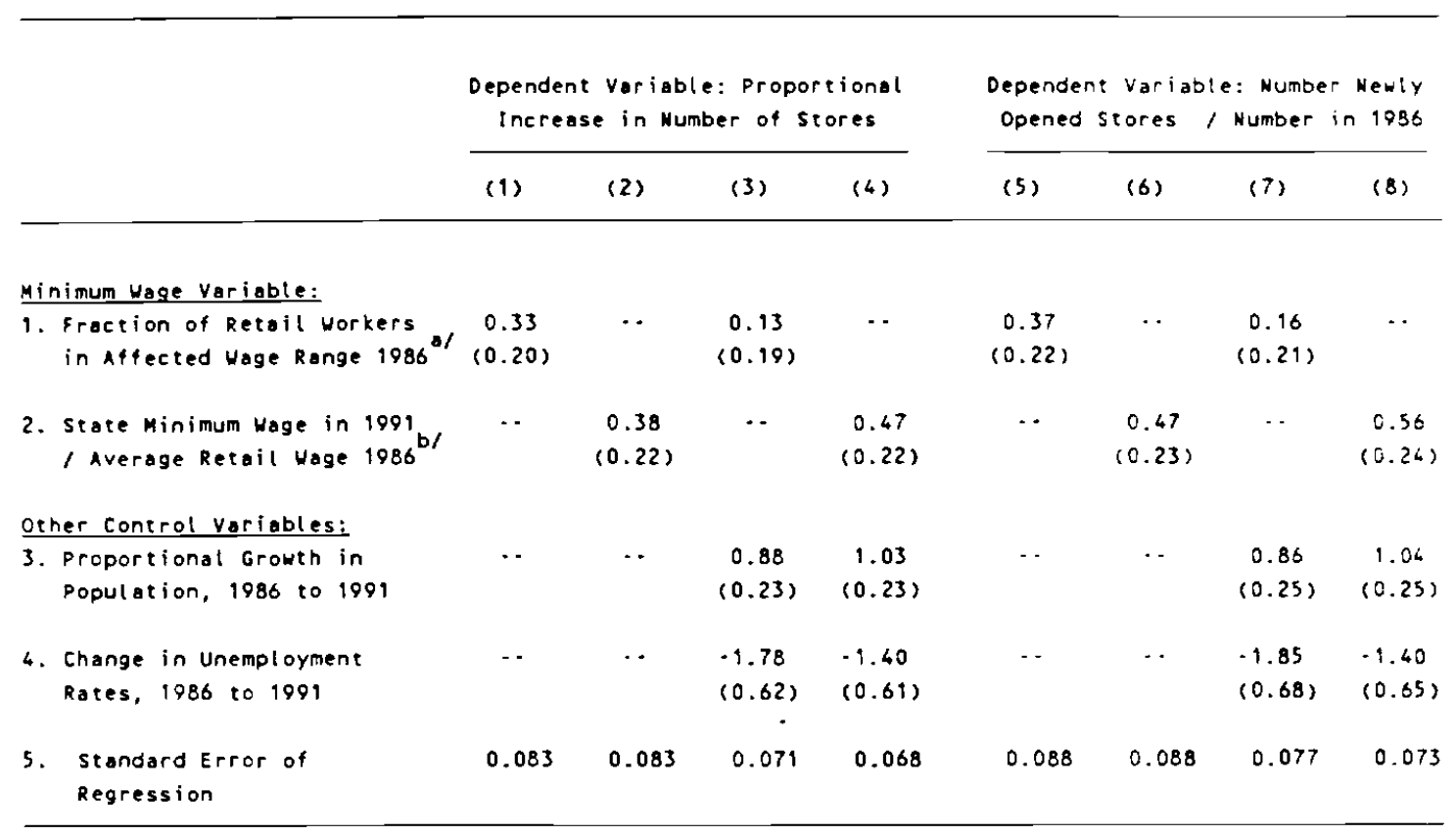

Notes: standard errors in parentheses. Sample contains 51 state-level observations (including 0.t.) on the number of McDonolds restaurants open in 1986 and 1991 . Dependendent variable in columns $(1)-(4)$ is proportional increase in the number of restourants open. Mean and standard deviation: are .246 and .085 , respectively. Dependendent variable in columns $(5)-(8)$ is ratio of the number of new stores opened between 1986 and 1991 to the number open in 1986. Mean and standard deviation are .293 and .091 , respectively. All regressions ore weighted by state population. in 1986 .

"Fraction of all workers in retail trade in the state in 1986 earning an hourly wage between $\$ 3.35$ per hour and the "effective" state minimum wage in 1990 (i.e., the maximimum of the federal minimum wage in $1990(\$ 3.80)$ and the state minimum wage as of Aprib 1990$)$.

b/

Maximum of state and federal minimum wage as of April 1 1990 divided by average hourly $-a g^{\circ}="$ workers in retail trade in the state in 1986. 


\begin{tabular}{|c|c|c|c|}
\hline & \multicolumn{3}{|c|}{ Employment-Population Rate: } \\
\hline & 1991 & 1992 & $\begin{array}{l}\text { Change: } \\
1992-1991\end{array}$ \\
\hline \multicolumn{4}{|l|}{ New Jersey } \\
\hline Teenagers & $\begin{array}{l}37.7 \\
(1.8)\end{array}$ & $\begin{array}{l}37.0 \\
(1.8)\end{array}$ & $\begin{array}{l}-0.7 \\
(2.2)\end{array}$ \\
\hline Age 25 and older & $\begin{array}{l}64.1 \\
(0.5)\end{array}$ & $\begin{array}{l}61.5 \\
(0.5)\end{array}$ & $\begin{array}{l}-2.6 \\
(0.6)\end{array}$ \\
\hline \multicolumn{4}{|l|}{ Pennsylvania } \\
\hline Teenagers & $\begin{array}{l}48.0 \\
(1.0)\end{array}$ & $\begin{array}{l}45.3 \\
(1.9)\end{array}$ & $\begin{array}{l}-2.7 \\
(2.3)\end{array}$ \\
\hline Age 25 and Older & $\begin{array}{l}58.8 \\
(0.5)\end{array}$ & $\begin{array}{l}59.1 \\
(0.5)\end{array}$ & $\begin{array}{c}0.3 \\
(0.6)\end{array}$ \\
\hline \multicolumn{4}{|l|}{ New York } \\
\hline Teenagers & $\begin{array}{l}31.4 \\
(1.3)\end{array}$ & $\begin{array}{l}28.6 \\
(1.3)\end{array}$ & $\begin{array}{l}-2.8 \\
(1.6)\end{array}$ \\
\hline Age 25 and older & $\begin{array}{l}59.6 \\
(0.4)\end{array}$ & $\begin{array}{l}58.6 \\
(0.4)\end{array}$ & $\begin{array}{l}-1.0 \\
(0.5)\end{array}$ \\
\hline \multicolumn{4}{|l|}{ All U.S. } \\
\hline Teenagers & $\begin{array}{l}43.5 \\
(0.4)\end{array}$ & $\begin{array}{l}42.4 \\
(0.4)\end{array}$ & $\begin{array}{l}-1.1 \\
(0.5)\end{array}$ \\
\hline Age 25 and older & $\begin{array}{l}62.7 \\
(0.1)\end{array}$ & $\begin{array}{l}62.5 \\
(0.1)\end{array}$ & $\begin{array}{l}-0.2 \\
(0.1)\end{array}$ \\
\hline
\end{tabular}

Notes: Estimated standard errors in parentheses.

Estimated from monthly Current population survey files for April-December of 1991 and 1992. 